\title{
Article
}

\section{Liturgy in Lockdown: Restricted Movement, Expanded Worship}

\author{
Deborah Ann Wong
}

check for

updates

Citation: Wong, Deborah Ann. 2022. Liturgy in Lockdown: Restricted Movement, Expanded Worship. Religions 13: 25. https://doi.org/ $10.3390 /$ rel13010025

Academic Editor: Edward Foley

Received: 26 November 2021

Accepted: 27 December 2021

Published: 28 December 2021

Publisher's Note: MDPI stays neutral with regard to jurisdictional claims in published maps and institutional affiliations.

Copyright: (C) 2021 by the author. Licensee MDPI, Basel, Switzerland. This article is an open access article distributed under the terms and conditions of the Creative Commons Attribution (CC BY) license (https:// creativecommons.org/licenses/by/ $4.0 /)$.
Duke Divinity School, Duke University, Durham, NC 27708, USA; debbie.wong@duke.edu

\begin{abstract}
What has the pandemic taught us about worship? Reflecting on religion in quarantine, Heidi A. Campbell observed that while many churches have embraced a new medium of worship (digital), the underlying approach to worship has remained centered on the worship event. Campbell criticizes this event-based focus as being out of step with the networked age in which we live. Is Campbell right, or is there still a place for the worship event, even in this networked age? Drawing on the work of liturgical theologians and network theorists, I revisit the role of the liturgical event in the wider life of the church, arguing that the liturgical event remains a central element of the church's mission, but that the liturgy is meant to take worshippers beyond itself. I suggest that pandemic reflections on liturgy should lead the church to emphasize that Christians are a sent people, even during a time of restricted movement. This shift in emphasis from gathering to sending out redefines the church more broadly and helps us reclaim a more expansive vision of worship beyond the mere event.
\end{abstract}

Keywords: liturgy; worship; pandemic; network; liquid church; sacramentality

\section{Introduction}

In Season 2 Episode 1 of the BBC television adaptation, Sherlock, starring Benedict Cumberbatch, Sherlock Holmes employs a simple trick to discover the location of his nemesis Irene Adler's concealed safe: he has his colleague, John Watson, set off the fire alarm. As soon as the alarm goes off, Adler's eyes flicker toward the mirror behind which the safe is hidden, thus revealing its location. "Fire exposes our priorities," Holmes explains. Our instinct is to save the thing that we treasure most. Fire-or in our case, a global pandemic - reveals what we value most.

When the global pandemic hit North America in March 2020, businesses, schools, and churches alike were thrown into a state of literal emergency, forced to make quick decisions about how to continue their work in the midst of lockdowns and directives on social distancing. The urgency of the situation and the limitations imposed meant that leaders had to triage: What do we save first? On what should we focus our limited resources and energies? What must be preserved in order to ensure the continued existence of the church?

The answer for most churches, it seems, was worship-in particular, the worship service.

Analyzing the results of a two-part survey (MacDonald et al. 2020) of over 1500 pastors and leaders, conducted in March and April 2020, Heidi A. Campbell observed that pastors "overwhelmingly ranked conducting weekend services as their priority" (Campbell 2020, p. 10), whether that meant moving services online or doggedly insisting on meeting in person, despite government regulations and recommendations to the contrary. Campbell, who studies digital religion and new media, observes that this response reveals a primarily event-based understanding of religion that she argues is out of step with the networked age in which we live-one in which people experience community as a social network of relationships, rather than being centered around a single group, such as the church (Campbell 2020, p. 11).

Campbell is right to suggest that a Christian community that understands itself solely or even primarily in terms of its ability to gather together is missing a crucial element ${ }^{1}$. 
However, it is a different thing to suggest that this gathering is irrelevant to the networked age altogether. This dichotomy between an event-based and a networked approach to religious community is a false one, especially for the Christian community, which has always been both a networked community and one that gathers to worship. In this article, I try to nuance Campbell's argument by suggesting that the worship event remains a central element of the church's mission but it can properly occupy this center only as part of a broader mission that extends into a wider, ever-expanding network. The very telos of the worship gathering is the sending of people out into the vast networks of which they are a part, and within which they are encouraged to participate fully as disciples of Christ.

I begin by first exploring the arguments in support of the alternative that Campbell suggests - that of a networked model of religious community. I then consider a theological argument for the centrality of the worship event, asking whether the event and network approaches are truly dichotomous. Finally, I conclude by suggesting that what is needed is not a decentering of the worship event from the church community but rather a reclaiming of the event more fully, as one that is concerned with creating and sustaining a networked community that is both local and global, both situated and dispersed, both gathered and sent out.

\section{Networked Religion: Beyond the Event}

We live in a networked world. This claim has been made so often by now that it has become something of a cliché. To use another phrase that has recently suffered the same fate, this networked world is our "new normal", and has been for some time already. The idea of a networked society has been around since at least 1991, with the publication of Jan van Dijk's book The Network Society (van Dijk 1991), but Niall Ferguson argues that humans are in fact inherently oriented toward forming social networks and have always done so (Ferguson 2017). The sociologists Nicholas Christakis and James Fowler observe that "our brains seem to have been built for social networks" (Christakis and Fowler 2009, p. 239), and historians William H. McNeill and J.R. McNeill suggest that the "first worldwide web" in fact emerged about 12,000 years ago (McNeill and McNeill 2003, p. 4). This fact of life has simply been amplified and brought to the fore by what Lee Rainie and Barry Wellman referred to as the "triple revolution" of the internet, social media, and mobile networks (Rainie and Wellman 2012, pp. 11-20). Social media has simply made visible the networks of which we were already a part.

Among the features of what Rainie and Wellman call this "new social operating system" are a move away from a group or institutional identity, toward "networked individualism" and a corresponding shifting of authority structures (Rainie and Wellman 2012 , p. 8). Whereas in the past, people's social networks used to be small and revolve tightly around family and community groups, they are now looser and more expansive. Where social relationships were once centered on these tightly knit groups, each individual is now the center of their own social network. With this shift comes a blurring of authority, as traditional hierarchies are diluted by the horizontal connections enabled by the social network. The Internet has made information that was once restricted to those with special expertise and training available to anyone with a smartphone who can spell "Wikipedia". Local pastors are no longer the only, or even the closest, spiritual authority to which individuals have access.

This shift in structure has been seen by some as a threat to the social fabric of society. In his study of America's declining social capital, Robert Putnam identified the shift away from group-based membership as a sign of the collapse of American community (Putnam 2000). Pastors and leaders of churches of all denominations, likewise, fear that the declining attendance at church services is a sign of decreased religiosity among their members. This focus on the number of worshipers in attendance is one of the negative outcomes that Campbell cites of an "event-based" approach to religious community (Campbell 2020). The assumption is that if people are not attending church, they are not engaging with or 
committed to their faith. With this approach, participation in the worship event is seen as the marker of one's religiosity and faithfulness.

While the reality of dwindling church attendance has led some pastors to double down on their efforts to make church services more engaging, in order to attract (and retain) members, a recognition of our networked reality has led others to adopt a different strategy. Instead of trying to bring people to church, they focus on bringing the church to where people already are. As early as 2002, Pete Ward began imagining what this might look like, expounding a vision of what he called the "liquid church" (Ward 2002). In contrast to a "solid church", which has at its center some form of congregational gathering (Campbell's "worship event"), a liquid church is fluid, taking its shape from the network of relationships that constitute it (Ward 2002, p. 48) ${ }^{2}$. In place of attending a weekly worship event, Ward suggests that the emphasis of a liquid church is "on living as Christ's body in the world" (Ward 2002, p. 2).

More recently, Keith Anderson has described this strategy in terms of a "digital cathedral," drawing on historic models of cathedrals that stood at the center of the city, in terms of both physical and social location (Anderson 2015). Like Ward's liquid church, Anderson writes that the "digital cathedral" is an invitation to "a more expansive understanding of church, and ways of being church, at a time when our definitions of church have become all too narrow, too parochial" (Anderson 2015, p. 20)_too "event-based," Campbell might say (Campbell 2020). Although much contemporary discussion (especially since the pandemic) has centered specifically on the church in relation to digital networks, Anderson notes that the idea of a digital cathedral is not solely a case of an online or digital church. Rather, this "networked, relational, and incarnational approach to ministry" urges church leaders to step out of the church and "be present in the places people work, live, and play," and to pay attention to the spirituality of everyday life, distinct from "the formal spirituality of the institutional church" (Anderson 2015, p. 30).

Anderson tells of ministry initiatives ranging from theology pub gatherings to Bible studies held in coffee shops, to handing out coffee and donuts on a street corner, as examples of this way of living "in cathedral" (Anderson 2015, p. 8). Each of these initiatives represents an attentiveness to the spirituality of everyday life-what Jeanne Halgren Kilde describes as a "situational" approach to sacred space, in which sacred space is constructed by the actions and meanings that humans assign to it. This stands in contrast to a "substantive" approach, which limits sacred space to designated "religious" places like churches (Kilde 2008). The situational approach, represented by Ward's liquid church and Anderson's digital cathedral, expands the religious community beyond the church building by recognizing ordinary places as sacred too. Reflecting the features of our networked age, it decenters the traditional hierarchical structure that constrained the religious community within the church's walls, creating space to acknowledge that there are other ways to engage faithfully in religious community outside of participation in the worship event.

However, this raises a key ecclesiological question: Is participation in a worship service equivalent to participation in any gathering of Christians? Are theology pub gatherings to be considered a substitute for participation in the liturgy, or is there something about the formal liturgical event that still warrants a significant place in churches' understanding of religious community? Put differently, is it enough simply that we gather, or do how we gather and what we do when we gather also make a difference? Is there still a place for the worship event in this networked, liquid age?

\section{What Is at Stake in the Worship Event?}

Those who advocate a networked approach to religion point to the fact that God is present everywhere, not limited by time or space, that God is not limited to the church, that everyday ordinary places can themselves be imbued with sacred significance and likewise be places where one might encounter God-and they are surely correct. Yet all around the world, Christians continue to meet to worship together. Is this simply, as Campbell 
suggests, a failure to adapt to the reality of the networked age? Or is there something about the worship event that remains valuable, even in this liquidized and networked age?

The pastors in the survey that Campbell analyzed evidently believe that the worship event continues to hold a place of importance in the Christian life, and they are not alone in thinking so. The Church has traditionally heeded the exhortation of the writer of the letter to the Hebrews to not neglect meeting together (Hebrews 10: v. 25) as a divine injunction to gather regularly in worship ${ }^{3}$. But what is it that we do in worship that makes it so important? Or, perhaps, the better question is: what is it that worship does to us?

Firstly, worship forms us. Liturgical theologians speak of the liturgy as being "formal," which is to say that it has the capacity to create form-to shape those who participate in it (Fagerberg 2011). Aidan Kavanagh is reported to have often remarked, "I don't go to Mass because I'm Catholic, I'm Catholic because I go to Mass". The liturgy, enacted in the worship event, is not simply about Christians gathering - it is an important factor in what forms them into Christians in the first place. In the worship event, God acts through the liturgy to shape us into God's people, a people who, among other things, are able to recognize God's presence and work in the world, and to see all of creation as sacred.

The everyday spirituality for which network models of religious community call requires a sacramental vision that does not come naturally to fallen, sinful humans. As Alexander Schmemann argues, however, the true reality of the world is that it is "shot through with the presence of God", although we may often fail to see it as such (Schmemman 2018, p. 17). This sacramental approach to the world is, in fact, the natural way in which Christians ought to experience the world, but in order to do so, our vision must be renewed such that we, in St. Ignatius of Loyola's words, might "see God in all things". What we do in the worship event forms in us this capacity to see sacramentally-in St. Augustine's terms, to see one thing, yet perceive another (Augustine 1993).

The "official" sacraments, whether seven or two or another number, are clear places where we learn this sacramental vision. In the waters of baptism, and the bread and wine of the Eucharist, we learn that ordinary things can be vehicles for the extraordinary (Schmemman would say that it is the "extraordinary" that is, in fact, ordinary in the true reality of God's kingdom). Similarly, Thomas Groome writes that "the great sacraments are simply climactic celebrations of the sacramentality of life" (Groome 2012), intensifications of the general sacramentality that can be found in the world. Yet, even churches that do not have the sacraments at the center of their worship each week offer opportunities to be trained in this sacramental vision. The very assertion that the church is the body of Christ requires the ability to perceive a spiritual reality beyond the physical. How else are we to believe that these people with whom we have gathered-some of whom may, in fact, be strangers to us, others with whom we would like to have nothing to do-are related to us by a bond that is stronger and more binding than the blood that ties us to our earthly families? What is more, how else are we to believe that this ragtag bunch of people are somehow the embodiment of Christ on this earth?

The proper focus of the worship event, then, is not mere attendance but transformation, with an eye toward daily Christian living. The philosopher James K.A. Smith reminds us that the "formal" nature of liturgy is not limited to Christian worship. Smith asserts that we are constantly being formed by the practices and liturgies in which we participate, including cultural and "secular" practices that are as seemingly mundane as a shopping trip to the mall (Smith 2009). In particular, Smith argues that our actions are governed by desire, and it is our desires that are subject to this formation (and malformation) (Smith 2009 , p. 53) ${ }^{4}$. All liturgies promote a certain vision of the good life and shape our desires accordingly. The worship event is thus critically important because it serves as "a counterformation to the mis-formation of secular liturgies into which we are 'thrown' from an early age" (Smith 2009, p. 88). Not only does it renew our vision, so that we are able to see all of creation as sacraments of God's grace but it also forms in us the desire to bear witness to God's grace in the world as the body of Christ, ourselves becoming signs of God's grace. Participating in the Christian worship event also shapes us to be the kind of people who 
desire to fulfill the goals of Ward's liquid church, Anderson's digital cathedral, and other networked approaches to church and religion-namely, to "[live] as Christ's body in the world" (Ward 2002, p. 2).

This leads to a second, related point: in the worship event, we are commissioned for this very thing: to be the body of Christ in the world. The worship event does not end with us simply leaving because the event is over. Rather, having been transformed through our encounter with Christ in worship, we are sent out-commissioned - to "be for the world the body of Christ," as the United Methodist Communion liturgy states. In his forthcoming book, Edward Foley makes a compelling case that the Eucharistic liturgy of the Catholic church is essentially an amplification of the Great Commission to "go forth and make disciples of all nations" (Matthew 28: v. 19) (Foley Forthcoming). Yet, again, even in the absence of the Lord's Supper in a worship service, Constance Cherry (2012) writes that the worship event most appropriately finishes with a blessing and a charge (commission), such as, "Go in peace (blessing) to love and serve the Lord (charge)". The "end" of worship is the "beginning" of mission; but, more accurately, they are one and the same.

In gathered worship, we are constituted as the body of Christ, the church. Inherent in this constitution is a responsibility to continue God's mission, Christ's work on earth. While Jesus walked the earth, anyone wanting to receive a blessing could simply approach him. Crowds came from miles away to listen to him speak words of life. When a man needed healing, he waited for Christ to pass by and cried out, "Son of David, have mercy on me!" The blind man asked to see, and Jesus spat on the ground and rubbed the mud on his eyes. While Jesus walked the earth, it was obvious where you needed to be if you needed something only Christ could give. Since the Ascension, however, Jesus is no longer physically on earth. How, then, can anyone receive healing, salvation, forgiveness, or grace from the Lord? Who will do the Father's work, now that Christ is no longer physically present for the world to interact with" ? Karl Rahner asserts that "[the church] is the primary sacrament through which Christ manifests and effects his saving grace in the world" (Skelley 1991, p. 156). If the Church takes seriously the proposition that she is now the body of Christ in the world, and the means through which Christ communicates his grace, the Church must always fulfill its mission in and to the world to proclaim good news to the poor, bind up the brokenhearted, proclaim freedom for the captives, care for the widows and orphans, and look after the least of these.

The incarnational ministry that appeals to proponents of networked religion is, thus, most properly understood as the natural outcome of the church at worship-the way the church fulfills its commission. Far from being at odds with one another, the worship event and the network model are two sides of the same coin. The worship event is never to be seen as self-contained, but as having a telos that is aimed outward, sending the people of God forth into the world, with the ability to witness to the work of God in everyday life as they live in networked community with others. Failure to attend to this telos results, as Campbell rightly observes, in too narrow an understanding of religious community-as well as too narrow a view of the worship event (whether online or in person). If the worship event is seen as an end in itself, its telos remains unfulfilled. Fagerberg speaks of the worship event as merely the "tip of the liturgical iceberg," the part visible above water (Fagerberg 2011). This image reinforces the idea that although the event is seen to be central to Christian community, it does not-and cannot - exist in isolation. Furthermore, to focus only on the tip of the liturgical iceberg is to fall prey to what Paul Holmer terms "liturgical hyperconsciousness," becoming overly conscious and enamored of the liturgy rather than allowing the liturgy to make us conscious of God, and the mission of God in which God has called us to participate (Holmer 1976, p. 24). Conversely, an overemphasis on the "mission" without the worship risks reducing that missionary work in networks to little more than human activity. The missiologist David Bosch reminds us that the church engages in mission not chiefly as a work of its own but in order to be a reflection of Christ in the world (Bosch 1991) ${ }^{6}$. That is, being missional is simply part of who God is, and thus by extension, who the church ought to be. The mission belongs to and begins with 
God, not the church. In worship, the Church receives her commission to participate in this mission of God. Far from narrowing the definition of religious community, then, a proper understanding of the worship event as being inextricably linked through mission to the worshipers' networked reality results in the possibility of an ever-expanding religious community-one that spreads out in the form of a network but that is gathered at and by a central hub.

\section{Conclusions}

The idea I have put forth here, that the church's worship life extends beyond the worship event, is not a novel one. It has, however, at times been obscured or forgotten, resulting in a division between what many have referred to as the church's gathered worship and scattered worship ${ }^{7}$. The church gathers to worship (in the "worship event") and then scatters to live out God's mission in the world through networks of which the worshipers are a part. Both are an integral part of what it means to worship, and thus the worship event cannot be seen as an outdated model of the church's life together-it is merely an incomplete one. Even in his proposal of a liquid church model, Pete Ward acknowledged that "worship and meeting with others will still have a place" (Ward 2002, p. 2). Both Ward's (2002) and Anderson's (2015) underlying concerns about the established church seem not to be with a sense of its outdatedness, but with its insularity and narrowness in terms of effectively confining God to the church building or worship event. That is, what is "out of step with the networked age" (Campbell 2020) is not the fact that the church meets to worship together but that it expects this event to be the primary mode of mission. Sadly, the modern church has, indeed, often prioritized the gathering to the exclusion of the sending. However, the solution is not to do away with the gathering but to reclaim it in its entirety-as the hub that centrifugally powers the many nodes linked to it in the larger network.

What does all this mean for the liturgy in the midst of a pandemic? First, I believe it affirms the instincts of those pastors and leaders who focused on trying to maintain a worship gathering. At the same time, however, it reminds us that the goal of these offerings is not simply to reach a certain level of viewership or attendance. Understandably, many pastors lament the lower viewership for their online services, compared to in-person attendees, fearing that their congregants are no longer engaging in religious community. The fear is a valid one, but an expansive, outward-facing understanding of the worship event reminds us that viewership numbers might not be the best metric to focus on, whether in terms of accuracy or mission. Instead, a properly balanced approach that recognizes the telos of the event to be the commissioning of its participants "to be for the world the body of Christ" should have as one of its main goals the equipping of the people being sent forth.

In any case, anecdotal evidence suggests that while some have indeed stopped going to church altogether and have not engaged in alternative forms of religious activity, many others have found new ways of worshiping through the practices of morning and evening prayer, liturgies written for "the ordinary events of daily life" ${ }^{\prime}$, and various online religious communities on social media. They have found ways to live in the sacramentality of everyday life, knowing that God's gifts of grace are not out of reach. Thus, the fearful conclusion that congregants who are not attending services online have forsaken worship practices altogether may not be entirely true.

In cases where it is true, what should trouble pastors most is not the fact that these congregants are not attending church but that their previous participation in worship has not formed them into a people whose worship continues even beyond and in the absence of the worship event ${ }^{9}$. This should be a concern even during non-pandemic times, but just as the pandemic reveals our priorities, it exposes our vulnerabilities and draws our attention to areas that may have otherwise been neglected. The role of the worship event has not changed as a result of the pandemic, but, in the wake of COVID-19, online church services, and incredible Zoom fatigue, some churches may find that they have been guilty of a kind of "liturgical hyperconsciousness" (Holmer 1976, p. 24), concerned more about 
the execution of the liturgical event than its formative power. A crucial question that the pandemic should be leading church leaders to ask, then, is: How is the way that we conduct worship forming, or failing to form, in parishioners the capacity to approach sacred space situationally, to see in every place, person and ritual the possibility of an encounter with the living God?

Perhaps more specifically, how do we teach and encourage parishioners to pay attention to the spirituality of everyday life, such that, even in the absence of regular weekly gatherings, they might continue to recall the life, death and resurrection of Christ and live accordingly as faithful disciples of Christ? How do we help parishioners to understand the mission with which they are sent forth from the worship event into the world, especially at a time when the world into which they are sent forth is one largely confined within the walls of their home? What resources are we providing or failing to provide for parishioners to equip them to develop these capacities? Furthermore, with many churches planning to continue meeting online beyond the end of the pandemic, more creative attention needs to be given to how this formation can best be facilitated through both online and offline mediums. As media theorists have long insisted, the medium is not neutral, and different mediums (and contexts) require different approaches to the same issue. What works for an in-person assembly will almost certainly differ from what works best for an online assembly $^{10}$.

I have suggested that the worship event, properly conceived, is intended to point worshipers beyond the event (and themselves), that the directionality of its telos is outward, into the world (both physical and virtual). Having encountered Christ, His disciples were sent into the world with the promise that Christ would be with them always, and with an accompanying charge to make other disciples (Matthew 28: vv. 19-20). Rather than keeping worshipers captive to itself, the liturgy (by facilitating an encounter with the risen Christ) similarly sends us forth into the world and frees us to discern the light of Christ and the work of the Spirit more fully in the world at large. This enables worshipers to both appreciate and participate in the sacramentality of ordinary, everyday life, and to be for the world a kind of sacrament through which they might experience and encounter the grace of God. In this regard, although the pandemic has shaken the foundations of many churches' worship life in numerous ways, Christian communities might view it not as a restriction on their worship, but rather as an invitation to reclaim a more expansive vision of worship that begins in the event but continues far beyond it, inviting us to encounter and serve God everywhere and at all times-even in the midst of a global pandemic.

Funding: This research received no external funding.

Institutional Review Board Statement: Not applicable.

Informed Consent Statement: Not applicable.

Data Availability Statement: Not applicable.

Conflicts of Interest: The author declares no conflict of interest.

\section{Notes}

A crucial question the pandemic forced churches to wrestle with is that of whether a physical, in-person gathering is a crucial component of the church's identity, or if a virtual, online gathering can be considered equally legitimate. Along with scholars such as Berger (2017), Drescher (2011), Thompson (2016), Gorrell (2019) and others, this author affirms the basic legitimacy of online worship in terms of Christ's ability to be present online, and the possibility of meaningful connection with God and others. At the same time, I acknowledge that not all forms or practices of online worship are equal or equivalent (just as not all forms or practices of in-person worship are equal or equivalent), and that the medium itself does not guarantee any specific outcomes (see notes 3 and 10 for further discussion). Regardless of one's opinions on the matter, however, online worship is a given of our present and future age. The task at hand is to figure out how to do it well (and, indeed, what it means to worship well). Thus, rather than addressing the online versus in-person worship debate in detail (which would require an entirely separate article or series of articles in itself), the present article seeks to engage what I consider to be an even more foundational question, regarding the relationship between the Church's worship event and her participation in God's mission. The temptation and danger of 
seeing these elements as separate or separable is common to both online and in-person gatherings, and my contention here is that a clear vision of worship itself as part of this missionary endeavor must precede any strategies related to the technicalities of the gathering, whether in person or online.

2 Ward borrows the language of "solid" and "liquid" from the Polish philosopher and sociologist Zygmunt Bauman, who distinguishes between solid and liquid modernity. Bauman (2000) argued that modernity was in the process of being liquidized, such that individuals can no longer base their identity on organizations or institutions but must instead shape their identity through their own choices. Ward observes that whereas solid modernity spawned a solid form of church, the liquid modernity of the present demands a liquid form of church. For our purposes, we can consider this liquidized society synonymous with the networked age that we have been discussing.

3 Proponents of what Jay Kim (2020) calls the "analog church" argue that the kind of gathering that the writer of the letter to the Hebrews has in mind is an in-person one. They point to the Incarnation's implication of bodily significance and insist that Christian worship must take place in person if it is to avoid a Gnosticism that renders our physical bodies insignificant. The liturgical historian Andrew McGowan (2020) notes that Christian worship has generally implied a community that is physically present in one place. In response, advocates of online worship take the view expressed by Lawrence Lessig in his "The Zones of Cyberspace" (Lessig 1996) that "Cyberspace is a place. People live there". Incarnational living thus extends to cyberspace, which is no less real, although it may be virtual. Online worship is not, or at least need not be a disembodied experience. Cyberspace is, thus, seen as a new mission field in its own right, inviting the Church to extend Christ's ministry and presence to the ends of the internet. Surely, even there, Christ will be with them by the power of the Spirit. Of course, there is much more to be said about this debate. As mentioned earlier, however, I believe the conversation must move beyond a debate about the basic validity of online worship and focus instead on its potential for both formation and malformation, as well as what full, conscious, and active participation in online worship might look like. (Indeed, a renewed focus on these dynamics in in-person worship services is also needed!)

$4 \quad$ Key to Smith's argument is a theological anthropology that views humans as creatures of desire. Subverting the Cartesian notion that we are what we think, which has largely dominated Protestantism at least since the Reformation, Smith takes a more Augustinian view that humans are what we love. Thus, worship is one of the means through which we are taught to love rightly.

5 I am indebted to the liturgical historian Lester Ruth for this insight.

6 I am grateful to Edward Foley for introducing me to Bosch's work, and to the maxim that it is not that the church has a mission, but that God's mission has a church.

7 See, for example, a recent (modified) use of this phrase in (Hudson 2019). Hudson's argument is similar to mine: he argues that what the church does on Sunday ought to "empower people to live faithfully and fruitfully for Christ in their Monday-toSaturday lives".

8 See, for example: (McKelvey 2017) and (McKelvey 2021), (Stokes 2021), and (Bevins 2020).

9 This is what Karl Rahner refers to as "the liturgy of the world," which he views as having priority over "the liturgy of the church". In the framework I have laid out here, we might explain this priority in this way: our worship in church is meaningless if it does not lead to our worship being lived out in the world.

10 The theologian Deanna Thompson (2016) tells of her own conversion from a "digital skeptic" to a firm believer in the power and potential of virtual connectedness as a result of being bed-bound by cancer and, thus, being forced to rely on virtual means of finding and sustaining community. She is quick to point out, however, that digital technology itself does not guarantee community. Felicia Wu Song (2009) makes a similar observation, in Virtual Communities: Bowling Alone, Online Together, that virtual communities do not automatically introduce a new dynamic of community but in fact reinforce existing assumptions about the self and community. Along with Thompson, I believe that technology is best seen as a tool that complements and extends God's mission, as expressed in physical congregations to online spaces, and more attention needs to be paid to the unique gifts that various forms of technology bring to the table. I think the question of whether online worship can fully replace in-person worship is useful only insofar as it functions as a thought experiment to help us identify core liturgical concerns. The reality is that online worship is happening, for better and for worse. Each mode of worship, both analog and digital, offers different gifts to and through the church. A disembodied theoretical discussion about the superiority and inferiority of these modes ignores the local and specific contexts and the needs of individual congregations and congregants. What is clear from the last year and a half is that some people have found greater connection and meaning through worshiping online, while others have found themselves utterly unable to do so. Many who, because of illness, social anxiety, work, or a variety of other factors, would not otherwise step foot inside a church for worship have become faithful congregants online, while others who are unable to engage online have stopped attending worship altogether. My hope is that this discussion helps to facilitate a shift from a narrow debate between the absolute validity and superiority of an online or offline church to imaginative conversations about liturgical robustness and formation in a universal church that extends throughout the physical and virtual world.

\section{References}

Anderson, Keith. 2015. The Digital Cathedral: Networked Ministry in a Wired World. New York: Morehouse Publishing.

Augustine, Saint. 1993. Sermon 272. In Sermons:(230-272B) on the Liturgical Seasons, vol. III/7. Edited by John E. Rotelle. Translated by O.

P. Ed-Mund Hill. New York: New City Press. 
Bauman, Zygmunt. 2000. Liquid Modernity. Cambridge: Polity Press.

Berger, Teresa. 2017. @Worship: Liturgical Practices in Digital Worlds. New York: Routledge.

Bevins, Winfield. 2020. Living Room Liturgy. Franklin: Seedbed Publishing.

Bosch, David J. 1991. Transforming Mission: Paradigm Shifts in Theology of Mission. New York: Orbis Books.

Campbell, Heidi A. 2020. Religion Embracing and Resisting Cultural Change in a Time of Social Distancing. In Religion in Quarantine: The Future of Religion in a Post-Pandemic World. Edited by Heidi A. Campbell. College Station: Digital Religion Publications, Available online: https:/ /hdl.handle.net/1969.1/188004 (accessed on 17 November 2020).

Cherry, Constance. 2012. The Worship Architect: A Blueprint for Designing Culturally Relevant and Biblically Faithful Services. Grand Rapids: Baker Academic.

Christakis, Nicholas A., and James H. Fowler. 2009. Connected: The Surprising Power of Our Social Networks and How They Shape Our Lives. New York: Little, Brown.

Drescher, Elizabeth. 2011. Tweet if You [Heart] Jesus: Practicing Church in a Digital Reformation. Harrisburg: Morehouse Pub.

Fagerberg, David W. 2011. Being formed into liturgical people by an abiding lex orandi. Paper presented at Southwest Liturgical Conference, Salt Lake City, UT, USA, February 3.

Ferguson, Niall. 2017. The Square and the Tower: Networks, Hierarchies, and the Struggle for Global Power. London: Penguin Books.

Foley, Edward. Forthcoming. Eucharistic Adoration after Vatican II. Collegeville: Liturgical Press.

Gorrell, Angela. 2019. Always On: Practicing Faith in a New Media Landscape. Grand Rapids: Baker Academic.

Groome, Thomas H. 2012. What Makes Us Catholic: The Sacramental Principle. In C21 Resources. Boston: The Church in the 21st Century, Boston College, pp. 4-5.

Holmer, Paul. 1976. About Liturgy and Its Logic. Worship 50: 18-28.

Hudson, Neil. 2019. Scattered and Gathered: Equipping Disciples for the Frontline. London: Intervarsity Press.

Kilde, Jeanne Halgren. 2008. Sacred Power, Sacred Space: An Introduction to Christian Architecture and Worship. Oxford: Oxford University Press.

Kim, Jay. 2020. Analog Church: Why We Need Real People, Places, and Things in the Digital Age. Downers Grove: InterVarsity Press.

Lessig, Lawrence. 1996. The Zones of Cyberspace. Stanford Law Review 48: 1403-11. [CrossRef]

MacDonald, Andrew, Ed Stetzer, and Todd Wilson. 2020. How Church Leaders Are Responding to the Challenge of COVID-19. COVID-19 Church Survey Summary Report. Exponential. Available online: https://exponential.org/resource-ebooks/responseto-covid-19 (accessed on 10 November 2020).

McGowan, Andrew. 2020. Liturgy in a Time of Plague: A Letter to a Colleague. Blog Post. March 14. Available online: http: / / abmcg.blogspot.com/2020/03/liturgy-in-time-of-plague.html (accessed on 14 December 2021).

McKelvey, Douglas. 2017. Every Moment Holy. Nashville: Rabbit Room Press, vol. 1.

McKelvey, Douglas. 2021. Every Moment Holy. Nashville: Rabbit Room Press, vol. 2.

McNeill, John Robert, and William H. McNeill. 2003. The Human Web: A Bird's-Eye View of World History. New York: W.W. Norton \& Company.

Putnam, Robert. 2000. Bowling Alone: The Collapse and Revival of American Community. New York: Simon \& Schuster.

Rainie, Lee, and Barry Wellman. 2012. Networked: The New Social Operating System. Cambridge: MIT Press.

Schmemman, Alexander. 2018. For the Life of the World: Sacraments and Orthodoxy. Yonkers: St Vladimir's Seminary Press.

Skelley, Michael S. J. 1991. The Liturgy of the World: Karl Rahner's Theology of Worship. Collegeville: Liturgical Press.

Smith, James K. A. 2009. Desiring the Kingdom: Worship, Worldview, and Cultural Formation. Grand Rapids: BakerAcademic.

Stokes, Terry J. 2021. Prayers for the People: Things We Didn't Know We Could Say to God. New York: Convergent Books.

Thompson, Deanna A. 2016. The Virtual Body of Christ in a Suffering World. Nashville: Abingdon Press.

van Dijk, Jan A. G. M. 1991. De Netwerkmaatschappij: Sociale Aspecten Van Nieuwe Media, 1st ed. Houten: Bohn Staflen van Loghum.

Ward, Pete. 2002. Liquid Church: A Bold Vision of How to Be God's People in Worship and Mission-A Flexible, Fluid Way of Being Church. Peabody: Hendrickson Publishers, Inc.

Wu Song, Felicia. 2009. Virtual Communities: Bowling Alone, Online Together. New York: Peter Lang Publishing. 